\title{
SISTEM PELACAKAN EKSPEDISI UNTUK BARANG IMPOR PADA PT. FLORESTA TRANS INDONESIA
}

\author{
Adrianus Valentino Radho \\ Program Studi Informatika Fakultas Teknik \\ Universitas Wijaya Kusuma Surabaya \\ rianradho18@gmail.com
}

\begin{abstract}
Abstrak
PT. Floresta Trans Indonesia merupakan salah satu perusahaan yang bergerak dalam bidang jasa penanganan impor barang. Dalam pengiriman barang ke tempat tujuan, banyak permasalahan yang sering terjadi salah satunya pelacakan dari posisi barang yang sulit dilakukan. Tugas Akhir ini mengajukan mekanisme penjejakan posisi barang berbasis GPS Tracker untuk membangun sistem pelacakan ekspedisi secara real time, dimana sistem dapat menampilkan lokasi kendaraan ekspedisi melalui Google Maps dan informasi mengenai barang yang dikirim. Sistem ini membutuhkan aplikasi tambahan pada android untuk membantu mengakses koordinat pada gps. Sistem yang dibuat berbasis web dengan bahasa pemrograman PHP dan database MySQL. Metodologi pengembangan perangkat lunak menggunakan Waterfall.
\end{abstract}

Kata Kunci: GPS Tracker, Ekspedisi, Sistem Pelacakan, Google Maps, Android, Waterfall.

\begin{abstract}
PT. Floresta Trans Indonesia is a company engaged in the handling of imported goods. In sending goods to their destination, there are many problems that often occur, one of which is tracking the position of the goods which is difficult to do. This final project proposes a GPS Tracker-based tracking mechanism to build an expedition tracking system in real time, where the system can display the location of expedition vehicles via Google Maps and information about the goods sent. This system requires additional applications on Android to help access coordinates on GPS. The system is made web-based with the PHP programming language and MySQL database. The software development methodology uses Waterfall.
\end{abstract}

Keywords: GPS Tracker, Expedition, Tracking System, Google Maps, Android, Waterfall.

\section{PENDAHULUAN}

\subsection{Latar Belakang}

Di era moderen saat ini, teknologi menjadi kebutuhan dalam kehidupan sehari-hari, salah satunya dalam lingkungan perusahaan, teknologi menjadi salah satu faktor penting dalam kemajuan perusahaan tersebut. Dengan memanfaatkan teknologi, apa yang kita kerjakan di dalam perusahaan akan menjadi lebih simple, efektif, dan juga efisien. Gabungan antara telekomunikasi dengan teknologi komputer telah menghasilkan suatu perubahan di bidang sistem informasi, di mana hal ini sangat berperan di dalam meningkatkan produktifitas suatu perusahaan. [1]

PT. Floresta Trans Indonesia merupakan perusahaan yang bergerak dalam layanan Freight Forwarder.[2] Freight Forwarder adalah sebuah perusahaan yang bergerak dalam bidang jasa yang bertugas mengelola pengiriman dan penerimaan barang Ekspor dan Impor. [3] Perusahaan ini lebih fokus pada pengiriman barang impor. Dimana barang yang diimpor dikirim ke tempat tujuan sesuai dengan permintaan dari customer pemilik barang tersebut.
Dalam hal pengiriman, kepuasan customer merupakan salah satu prioritas yang diutamakan oleh perusahaan ini. Oleh karena itu dalam melayani customer perlu dilakukan pemantauan secara langsung terhadap kendaraan pengirim barang tersebut, untuk memastikan apakah barang yang telah dikirim tersebut sudah sampai ke tempat tujuan atau belum. Pemantauan posisi kendaraan pengirim barang ini sangat diperlukan oleh perusahaan untuk mengawasi barang yang dikirim, agar tidak terjadi hal-hal yang tidak diinginkan, seperti barang yang dikirim tidak sampai tepat waktu, hilangnya barang dan disalahgunakan oleh pihak yang tidak bertanggung jawab dan hilangnya komunikasi dengan supir karena berbagai alasan.

PT. Floresta Trans Indonesia ini masih menggunakan cara manual untuk memantau posisi barang yang dikirim, yaitu dengan menghubungi sopir melalui media komunikasi telepon atau sms. Sedangkan customer tidak dapat mengetahui secara pasti dimana posisi barang yang dikirim. Hal ini tentu berpengaruh terhadap kualitas pelayanan dari perusahaan ini. 
Dari permasalahan yang telah dibahas diatas maka penulis membuat Laporan Tugas Akhir dengan topik "Sistem Pelacakan Ekspedisi untuk Barang Impor pada PT. Floresta Trans Indonesia“. Adapun sistem yang dibuat ini berbasis website dengan menggunakan bahasa pemrograman PHP dan database MySQL, yang diharapkan dapat memenuhi kebutuhan dan keinginan perusahaan sehingga informasi yang dihasilkan lebih maksimal.

\subsection{Rumusan Masalah}

Berdasarkan uraian dari latar belakang yang penulis jelaskan di atas, maka permasalahan yang dikemukakan, yaitu :

1. Bagaimana mengetahui informasi status barang yang dikirim?

2. Bagaimana cara mengetahui data lokasi barang yang dikirim ?

3. Bagaimana cara memfasilitasi pertanyaan dan pengaduan dari customer.

4. Bagaimana cara mengetahui daftar muatan barang yang dikirim oleh tiap customer?

\subsection{Batasan Masalah}

Terdapat beberapa batasan masalah dalam penelitian ini yaitu :

1. Lokasi kendaraan dapat diakses apabila GPS dalam keadaan aktif dan tidak bermasalah

2. Pemantauan posisi kendaraan bergantung pada kualitas sinyal yang diperoleh gps

3. Sistem hanya menampilkan informasi status proses pengeluaran barang, proses pengiriman, barang terkirim.

4. Customer service hanya memfasilitasi pertanyaan dan pengaduan seputar kerusakan dan trouble dalam pengiriman barang.

5. Sistem menggunakan aplikasi tambahan yaitu tracksolid untuk menampilkan informasi lokasi dan fitur lainnya pada gps

\subsection{Tujuan}

Tujuan yang ingin dicapai dari penelitian ini yaitu:

1. Mengetahui informasi status barang yang dikirim

2. Membuat fitur pemantauan posisi barang yang dikirim

3. Memfasilitasi pertanyaan dan keluhan bagi customer yang bermasalah dengan barang kiriman.

4. Menampilkan informasi muatan barang yang dimiliki oleh setiap customer

\subsection{Manfaat}

Manfaat yang dapat diperoleh dari penelitian ini yaitu :

1. Memudahkan pihak perusahaan dan customer dalam memantau posisi barang yang dikirim
2. Mempermudah customer dalam menyampaikan keluhan terhadap barang yang bermasalah

3. Meningkatkan pelayanan yang memuaskan kepada customer

\subsection{Sistem Pelacakan Ekspedisi}

Sistem pelacakan kendaraan merupakan sistem yang melakukan pelacakan dan pengendalian kendaraan melalui komputer online, handphone, tablet, dan lainnya berdasarkan basis 7/24 berkat satelit Global Posetion Sistem. Sistem pelacakan kendaraan dapat melakukan penjejakan kecepatan kendaraan yang dapat dicatat seketika itu juga, rute yang telah lalui, titik stop, dan waktu berhenti pada peta yang menyediakan titik informasi dengan laporan dari berbagai waktu [5].

Pada intinya, sistem pelacakan kendaraan bekerja dalam lingkupan GPS, GSM/GPRS, peta digital dan beberapa aplikasi khusus. Perangkat data mobile yang terinstalasi pada kendaraan meneruskan dua buah informasi yang didapatkan dari satelit - satelit pada waktu real saat informasi satelit dan posisi satelit di orbit pada saat diteruskan dan mengirimkan informasi - informasi seperti suhu ke pusat kontrol dan komunikasi melalui jaringan GPRS atau GSM. Informasi yang diterima kemudian dikumpul oleh softwarenatau aplikasi khusus dan dicatat di sebuah bank data pada server. Pada sisi useer, kendaraan dapat dijejak pada riwayat yang telash tercatat atau tersimpan dan seketika itu juga melalui smartphone, komputer dan atau tablet dengan menggunakan software khusus sehingga dapat membolehkan untuk memvisualisasikan semua informasi dari kendaraan, dan untuk mengubah alaram dan status program kendaraan. Struktur ini menjadi dasar berfungsinya sistem pelacakan kendaraan.

\subsection{Ekspedisi}

Menurut Kamus Besar Bahasa Indonesia (KBBI), Ekspedisi adalah pengiriman barang, surat dan yang lainnya ataupun perusahaan pengangkut barang [6]. Secara umum, ekspedisi dikenal sebagai pengiriman barang dari suatu tempat ke tempat lainnya yang letaknya cukup jauh. Barang yang di kirim dalam ekspedisi dapat berupa barang kecil ataupun barang yang besar. Pengiriman barang dari suatu titik ke titik yang lain akan menjadi lebih mudah dengan menggunakan jasa ekspedisi.

Biaya jasa ekspedisi atau harga pengiriman barang akan dihitung berdasarkan massa barang dan jarak antar kota pengiriman yang ditempuh. Pada dasarnya, semakin dekat jarak pengiriman barang maka harga pengiriman semakin rendah.

Dalam beberapa jasa pengiriman barang, kita dapat melakukan cek resi atau cek status pengiriman barang secara online. Hal tersebut akan memudahkan kita 
untuk mengetahui sudah sampai dimana barang yang sedang dikirim. Hal tersebut dapat membuat kita dalam melakukan pemantauan yang jelas agar tidak terjadi keterlambatan dalam pengiriman.

\subsection{GPS (Global Positioning System)}

"GPS atau Global Positioning System merupakan sistem satelit navigasi dan menentukan posisi menggunakan satelit". Nama resmi dari GPS adalah NAVSTAR GPS, merupakan singkatan dari "NAVigation Satellite Timing and Ranging Global Positioning System". Perangkat ini didesain untuk menginformasikan posisi kendaraan, informasi mengenai waktu, secara langsung di seluruh dunia tanpa terpengaruh oleh cuaca dan waktu kepada banyak orang secara serentak, dan informasi kecepatan tiga dimensi. Pada saat ini, perangkat GPS sudah banyak dipakai oleh orang di seluruh dunia dalam berbagai bentuk aplikasi [7].

\subsection{Google Maps}

Untuk menggunakan Google Maps dari laptop atau personal computer, maupun menggunakan smartphone dapat dibuka pada alamat http://maps.google.com melalui alat browser seperti Chrome, Uc Browser, Firefox, atau alat browser lainya. Selain melalui browser di PC atau laptop, aplikasi Google Maps juga bisa diakses melalui perangkat mobile dengan sistem OS. Untuk menggunakannya, user smartphone cukup membuka aplikasi Google Maps yang sudah diunduh lewat penyedia jasa aplikasi pada perangkat smartphone seperti playstore dan sejenisnya, lalu tampilan peta akan ditampilkan oleh google maps.

\subsection{PT. Floresta Trans Indonesia}

PT. Floresta Trans Indonesia adalah perusahaan yang bergerak dalam layanan Freight Forwarder yang meliputi: Melayani Pembersihan, Ekspor-Impor, dan Grosir (Semua Masuk) Manajemen Bea Cukai (PPJK) Layanan Door to Door Melayani Pengiriman Domestik (Transportasi Darat, Laut dan Udara) Melayani Izin Perusahaan untuk Penerima Barang Impor (bawah nama) layanan cleomance custom yang sangat berpengalaman dalam mengelola kegiatankegiatan Clearance Bea Cukai untuk kegiatan Ekspor dan Impor di mana sangat memahami dan mengetahui semua peraturan tentang Bea Cukai di Indonesia [2].

PT. Floresta Trans Indonesia didirikan pada tanggal 5 November 2007. PT. Floresta Trans Indonesia sukses melakukan pengembangan perusahaannya dengan berkomitmen untuk memberikan kualitas layanan yang terbaik. Dengan tata usaha yang profesional, kinerja yang efektif serta efisien dan bertanggung jawab yang membuat perusahaan ini menjadi kepercayaan perusahaan-perusahaan importir besar maupun kecil di Indonesia.

\subsection{Waterfall}

Metode waterfall adalah model pengembangan sistem informasi yang sistematik dan sekuensial [10]. Metode Waterfall memiliki tahapan-tahapan sebagai berikut :

1. Requirements analysis and definition

Yaitu tahap untuk menganalisa kebutuhan pengguna kemudian didefinisi secara detail dan berguna sebagai spesifikasi sistem.

2. System and Software Design

Pada tahap ini kebutuhan yang telah ada pada tahap - tahap sebelumnya dibuat menjadi rancangan sistem. Maka terlihat gambaran model sistem yang akan dibangun. Desain dapat berupa rancangan user interface, rancangan basis data, rancangan proses bisnis dan lain-lain.

3. Implementation and unit testing

Setelah dilakukan perancangan perangkat lunak, dilakukan perealisasian sebagai serangkaian program. Dan dilakukan verifikasi untuk dilakukan pengujian bahwa unit telah memenuhi spesifikasinya.

4. Integration and system testing

Tahapan-tahapan ini dilakukan pengelompokan dari hasil pengujian dan program, bahwa perangkat lunak sesuai dengan kebutuhan perangkat lunak.

5. Operation and maintenance

Sistem yang telah dipakai dan dijalankan selanjutnya dilakukan perawatan agar selalu dalam kondisi dapat dijalankan, awet dan tidak terjadi trouble seta terlindungi oleh serangan dari luar.

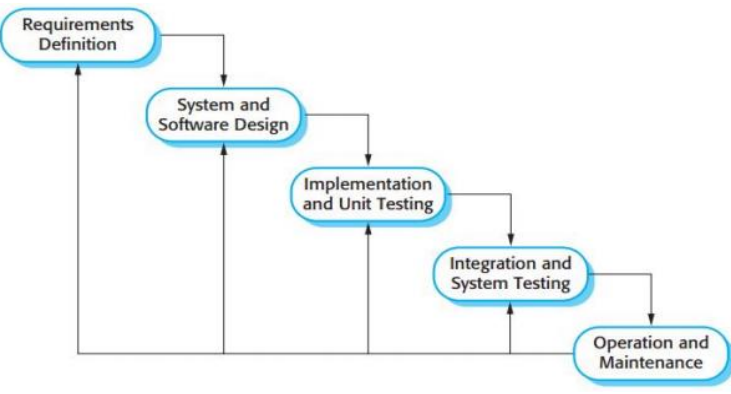

Gambar 1.1 Metodologi Waterfall [8]

\subsection{Android}

Android merupakan sesuatu sistem operasi untuk perangkat mobile berbasis linux yang mencakup sistem operasi, middleware dan aplikasi [18].

Menurut Akhmad Dharma Kasman (2016:2), "Android merupakan suatu sistem operasi pada 
perangkat telepon seluler, tablet layar sentuh atau touchsctreen dan komputer yang berbasis linux."

Akan tetapi seiring berkembangnya waktu, android kini telah berevolusi menjadi platform yang sangat cepat dalam berinovasi. Hal tersebut tidak lepas dari pengembang utama dibelakangnya yaitu Google. Google telah mengesahkan android, kemudian membuatkannya suatu platform. Platform android terdiri dari sebuah GUI (Graphic User Interface), sebuah web browser dan aplikasi end-user yang dapat kita download dan tentunya para developer dapat dengan leluasa berkarya serta menciptakan software yang terbaik dan terbuka untuk digunakan oleh berbagai macam perangkat yang tentunya sistem operasinya berbasis linux.

\section{METODE}

\subsection{Metode Pengumpulan Data}

Pada tahap ini, penulis melakukan pengumpulan data yang dilalui dalam 3 tahap yaitu wawancara, observasi dan studi pustaka.

1. Wawancara

Wawancara interaksi langsung di lapangan dimana ada proses tanya jawab langsung dengan customer dan pihak perusahaan untuk mengumpulkan data yang deperlukan dalam pembuata sistem pelacakan ekspedisi.

2. Observasi

Merupakan suatu metode untuk mengumpulkan data dengan pemantauan dan pencatatan secara langsung yang dilaksanakan di lokasi penelitian yaitu di PT. Floresta Trans Indonesia. Pada tahap ini customer dan staf tracking menajdi objek observasi informasi yang dibutuhkan untuk membuat sistem pelacakan ekspedisi.

3. Studi Pustaka

Tahap ini Penulis melakukan proses studi pustaka untuk memenuhi data dan informasi melalui buku - buku atau media baca lainnya dan beberapa situs pada internet yang berkaitan dengan pembuatan laporan dan aplikasi yang sedang dianalisis dan akan dibangun. Beberapa buku dan hasil pencarian dari beberapa situs di internet yang dipakai dalam penulisan laporan ini telah dicantumpkan dalam daftar pustaka.

\subsection{Analisa dan Definisi Kebutuhan}

\subsubsection{Analisa Kebutuhan}

Bagian tahapan ini dimana dilakukan sebuah analisa untuk menentukan kebutuhan penguna dari pokok permasalahan yang dihadapi. Proses analisa kebutuhan dilakukan dengan tahapan wawancara. Penulis mengajukan beberapa pertanyaan kepada pemilik perusahaan mengenai informasi perusahaan dan menanyakan kebutuhan yang diperlukan oleh perusahaan dalam proses pengiriman barang impor. Selama ini pihak perusahaan mengalami kesulitan dalam memantau posisi dan keadaan dari bekspedisi pengirim barang. Pihak perusahaan membutuhkan sistem informasi yang dapat membantu dalam pemantauan posisi kendaraan ekspedisi secara real. Diharapkan sistem pelacakan ekspedisi ini dapat memenuhi kebutuhan perusahaan dalam proses pengiriman barang impor dan dapat meningkatkan kualitas pelayanan kepada customer.

\subsubsection{Analisa Sistem}

\subsubsection{Data flow dyagram}

Dimana pada tahap analisa data flow dyagram akan dilakukan sebuah analisa sistem yang meliputi beberapa proses pada data flow dyagram sebagai berikut:

1. Data flow dyagram level konteks

Pada proses dfd level konteks, terjadi proses dimana pada proses ini meliputi alur kerja system yang digambarkan secara umum dimana pada tahap analisa dfd level konteks akan menganalisa data dan alur sistem untuk menghasilkan informasi sesuai dengan kebutuhan customer. Berikut adalah data dan alur pada kebutuhan sistem yang dianalisa secara umum. Berikut adalah alur pada sistem dengan data flow dyagram level context:

2. Dfd level 0

Dari Context Diagram selanjutnya akan didekomposisikan menjadi DFD Level 0. Proses yang digambarkan secara umum pada context diagram akan dipecah lagi menjadi beberapa proses yang lebih rinci dan detail. DFD level 0 terdiri dari 8 proses seperti yang terlihat pada gambar 2.2 berikut

3. Dfd level 2 Proses input data utama Pada tahap ini dijelaskan secara rinci dari proses 1 input data utama. Seperti pada gambar 2.3 berikut

4. Dfd level 1 proses set gps pada kendaraan Proses ini adalah hasil decompose dari proses 2 set gps pada kendaraan. Bagian ini akan dijelaskan secera rinci bagaimana proses seting gps pada kendaran seperti pada gambar 2.4 berikut

5. Dfd level 1 proses 3 transaksi barang

Proses ini merupakan hasil decompose dari proses transaksi barang, dimana pada proses ini dijelaskan lebih rinci bagaimana alur dari proses transaksi barangseperti pada gambar 2.5 berikut

\subsection{Design}

Setelah melakukan tahap analisa, tahapan selanjutnya akan mengambarkan desain dari sistem yang akan dibangun dengan membuat desain basis data pada sistem kemudian diproses oleh sistem agar dapat memberikan hasil informasi sesuai dengan kebutuhan 
penguna yang menjadi tujuan dalam pembuatan sistem pelacakan ekspedisi. Setelah pembuatan desain

basis data, selanjutnya membuat desain tampilan agar penguna dapat memasukan data dengan terstruktur sesuai dengan kebutuhan sistem.

\subsubsection{Desain Basis Data}

Desain databases sistem adalah tabel yang saling berelasi dan terstruktur untuk menyimpan data dan menghasilkan informasi sesuai dengan kebutuhan user.

1. Conseptual Data Model

Conceptual data modeling adalah konsep struktur data yang saling berelasi untuk mengahasilkan suatu informasi yang dibutuhkan oleh user pada sistem pelacakan ekspedisi yang mau dibuat. Sistem pelacakan ekspedisi ini mempunyai desain conceptual data model yang memiliki tujuh entitas yang saling berelasi, yaitu entitas supir, kendaraan, gps, customer, barang, masalah dan entitas pengiriman. Berikut adalah gambar conceptual data modeling pada sistem pelacakan ekspedisi :

2. Desain Physical Data Model

Phisycal data model adalah gambaran fisik tabel yang dihasilkan dari entitas conceptual data model yang dibuat. Dari fisik tabel tersebut memiliki beberapa relasi yang dihasilkan melalui kardinalitas entitas yaitu one to one, one to many, many to one dan many to many . Pada tabel tersebut memiliki pk(primary key) yang menjadi kardinalitas one dan fk(foreign key) menjadi kardinalitas many. Berikut adalah gambar desain pdm :

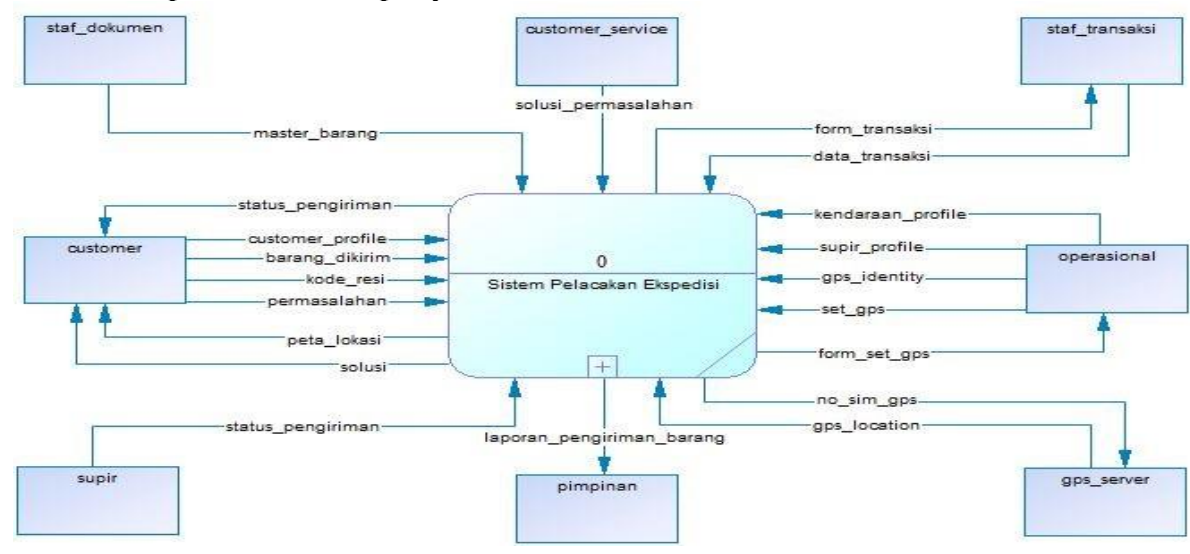

Gambar 2.1 dfd level konteks

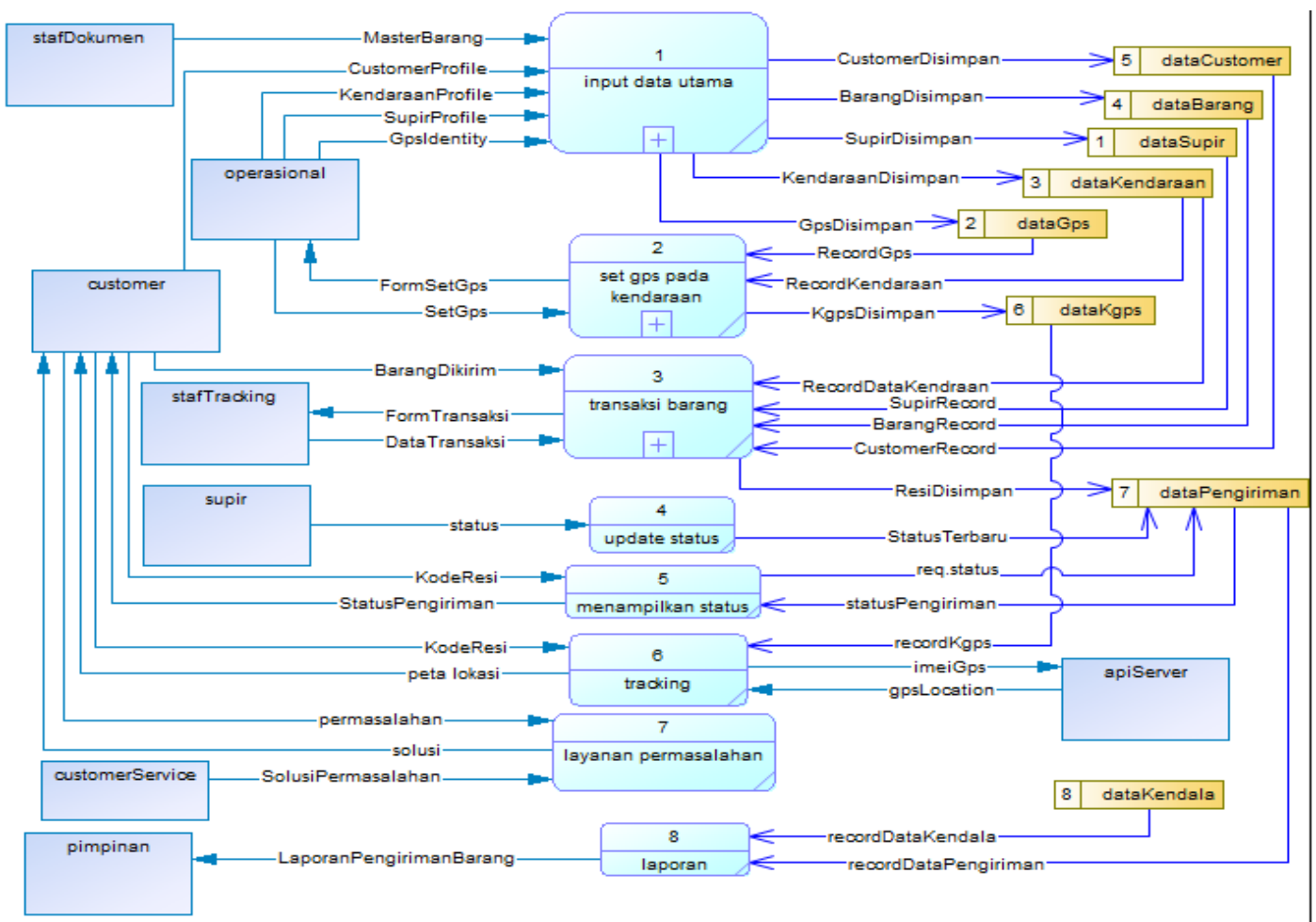

Gambar 2.2 dfd level 0 

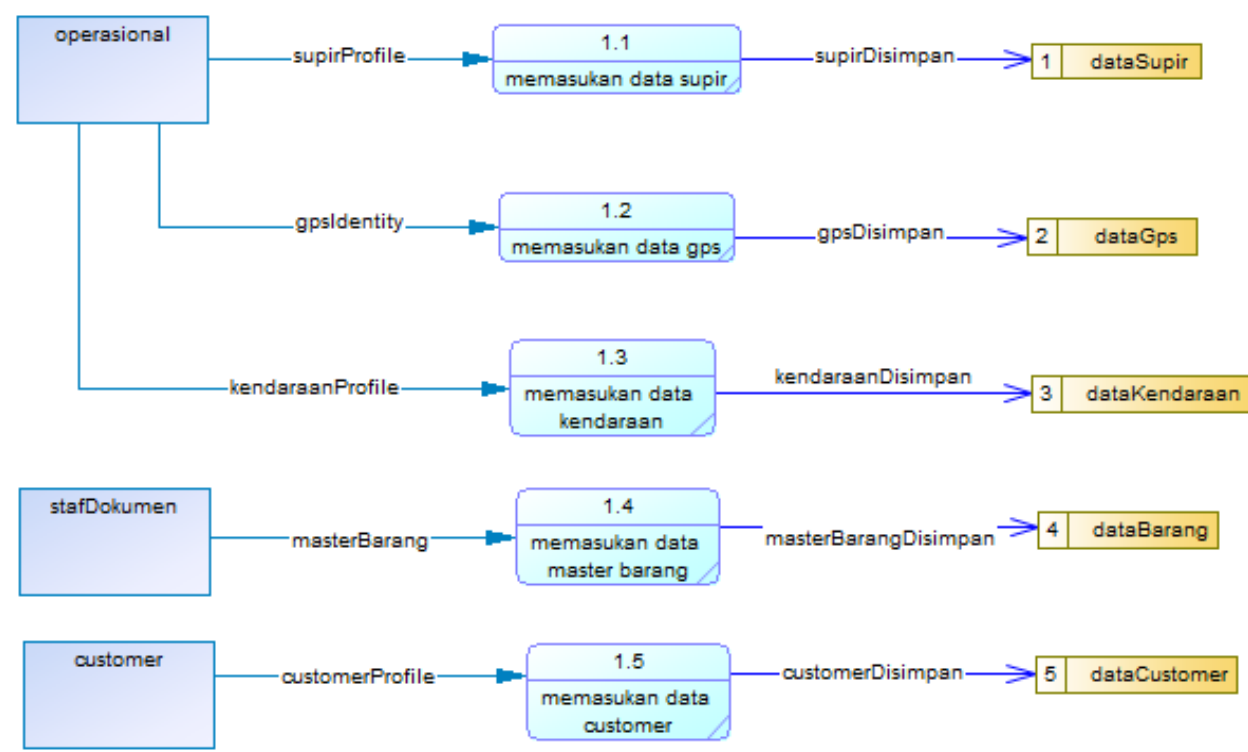

Gambar 2.3 dfd level 1 proses input data utama

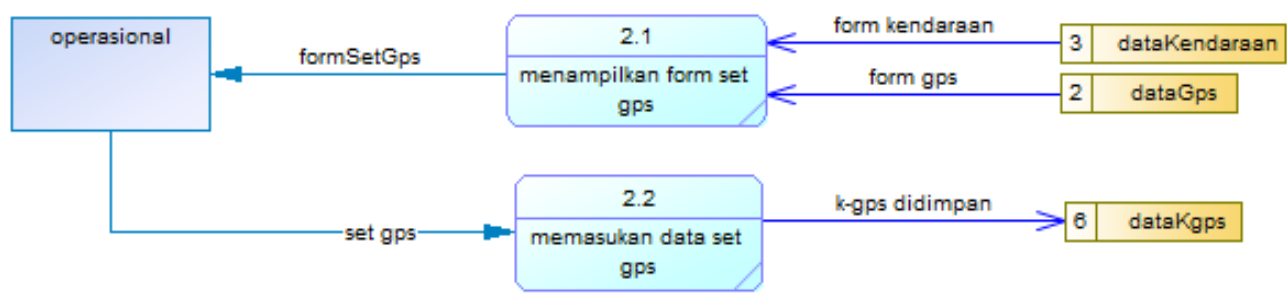

Gambar 2.4 dfd level 1 proses set gps

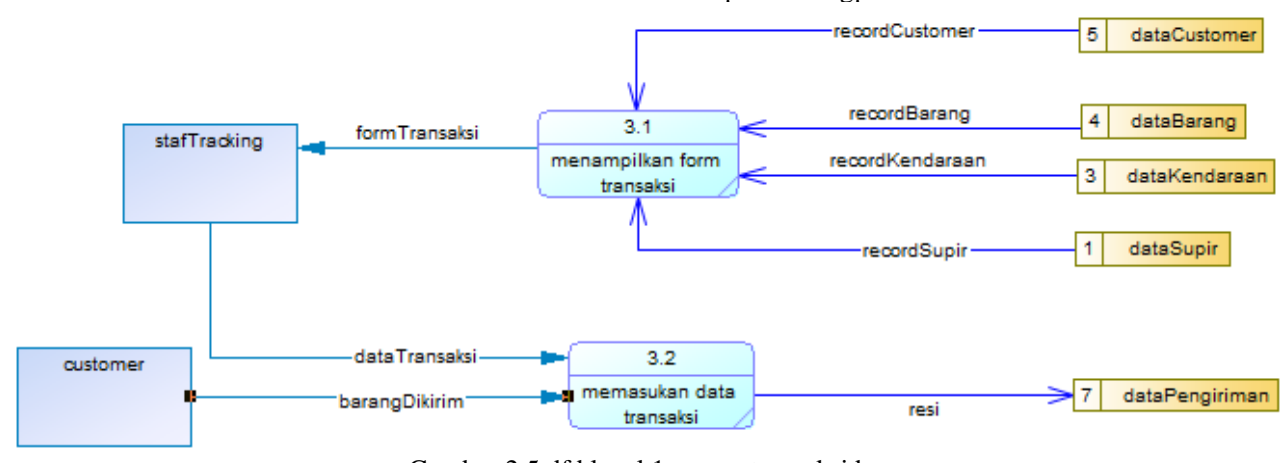

Gambar 2.5 dfd level 1 proses transaksi barang

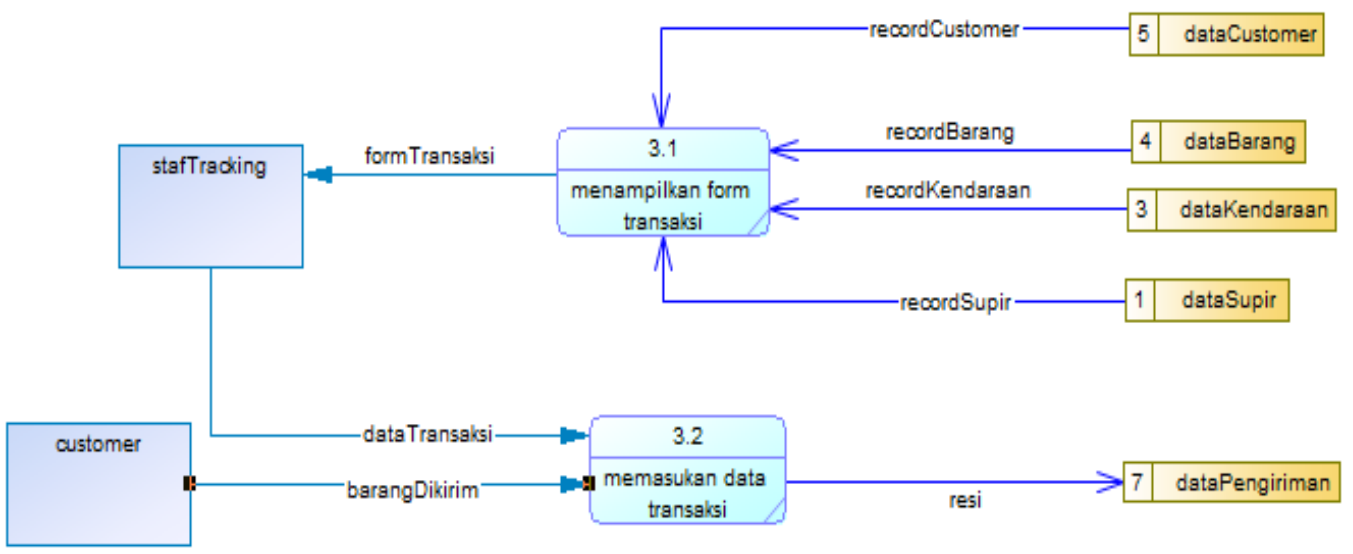

Gambar 2.5 dfd level 1 proses transaksi barang 


\subsubsection{Desain algoritma proses}

Berikut adalah desain algoritma proses yang digambarkan dalam model flowchart diagram.

1. Flowchart proses 5

Berdasarkan proses 5 pada data flow dyagram yaitu proses menampilkan status, maka desain flowchart seperti ditunjuk pada gambar 2.8 berikut.

2. Flowchart proses 6

Berdasarkan proses 6 pada data flow dyagram yaitu proses tracking, maka desain flowchart seperti ditunjuk pada gambar 2.9 berikut.

3. Flowchart proses 3

Berdasarkan proses 3 pada data flow dyagram yaitu proses laporan, maka desain flowchart seperti ditunjuk pada gambar 2.10 berikut.

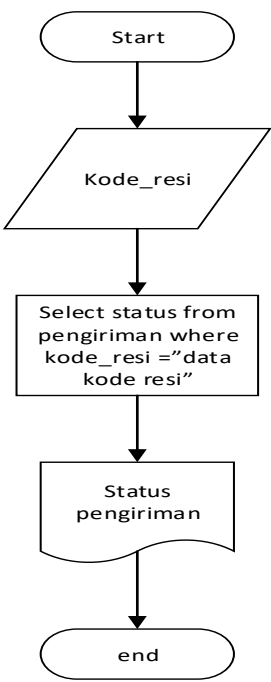

Gambar 2.8 desain flowchart proses 5

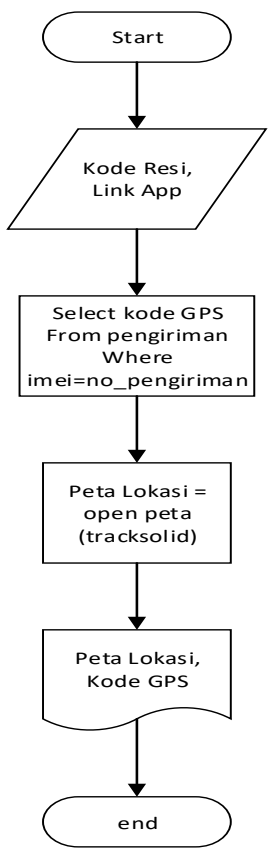

Gambar 2.9 desain flowchart proses 6

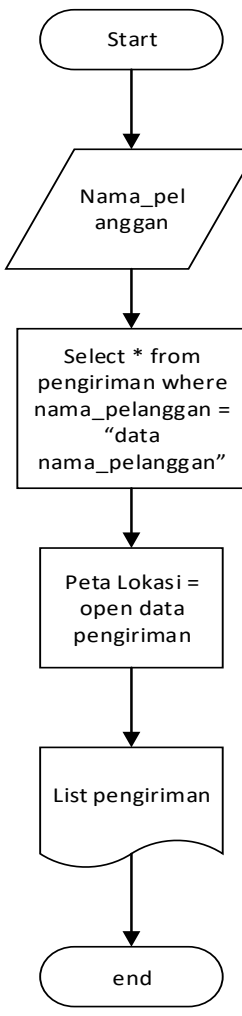

Gambar 2.10 desain flowchart proses 3

\subsubsection{Desain user interface}

Berikut adalah desain user interface sistem pelacakan ekspedisi pada PT. Floresta Trans Indonesia

1. Halaman login

Desain ini adalah halaman login yang digunakan oleh admin, pimpinan perusahaan dan customer service seperti pada gambar 2.11 berikut

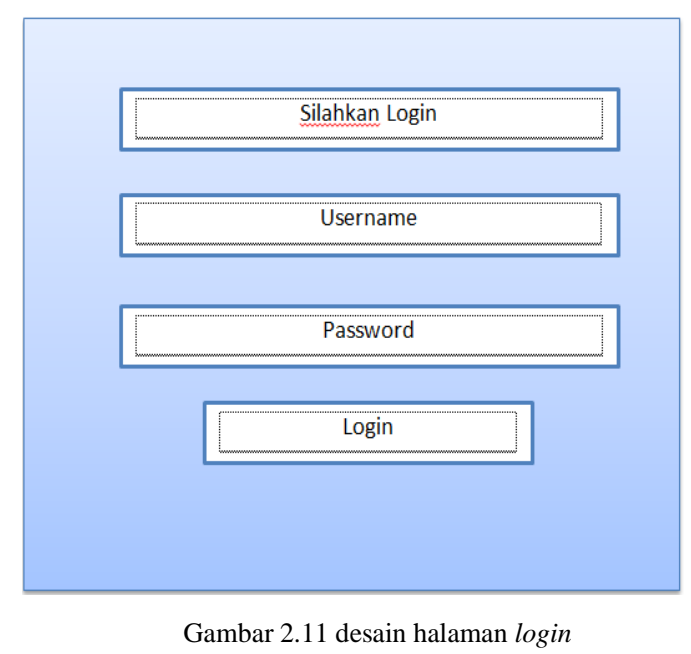

2. Halaman dashboard

Pada desain interface dashboard admin, disini adalah halaman kerja admin, dimana admin bisa mengupdate dan menambahkan data yang berhubungan dengan sistem pelacakan ekspedisi. 


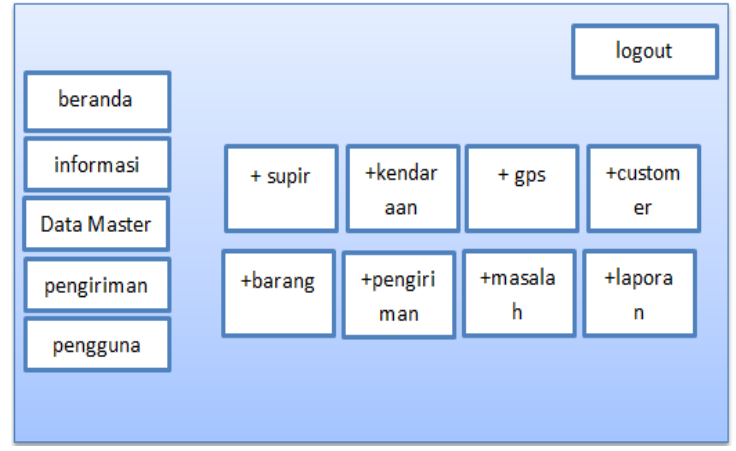

Gambar 2.12 desain halaman dashboard

\section{HASIL DAN PEMBAHASAN}

\subsection{Uji Coba Sistem}

Tahap uji coba sistem ini, penulis melakukan proses uji coba sistem untuk memastikan apakah sistemnya dapat berjalan dengan baik dan sesuai dengan espektasi atau belum.

\subsubsection{Uji Coba Proses Menampilkan Status Barang}

Tahap pertama dalam proses menampilkan status barang adalah admi terlebih dahulu login untuk masuk ke halaman kerjanya.
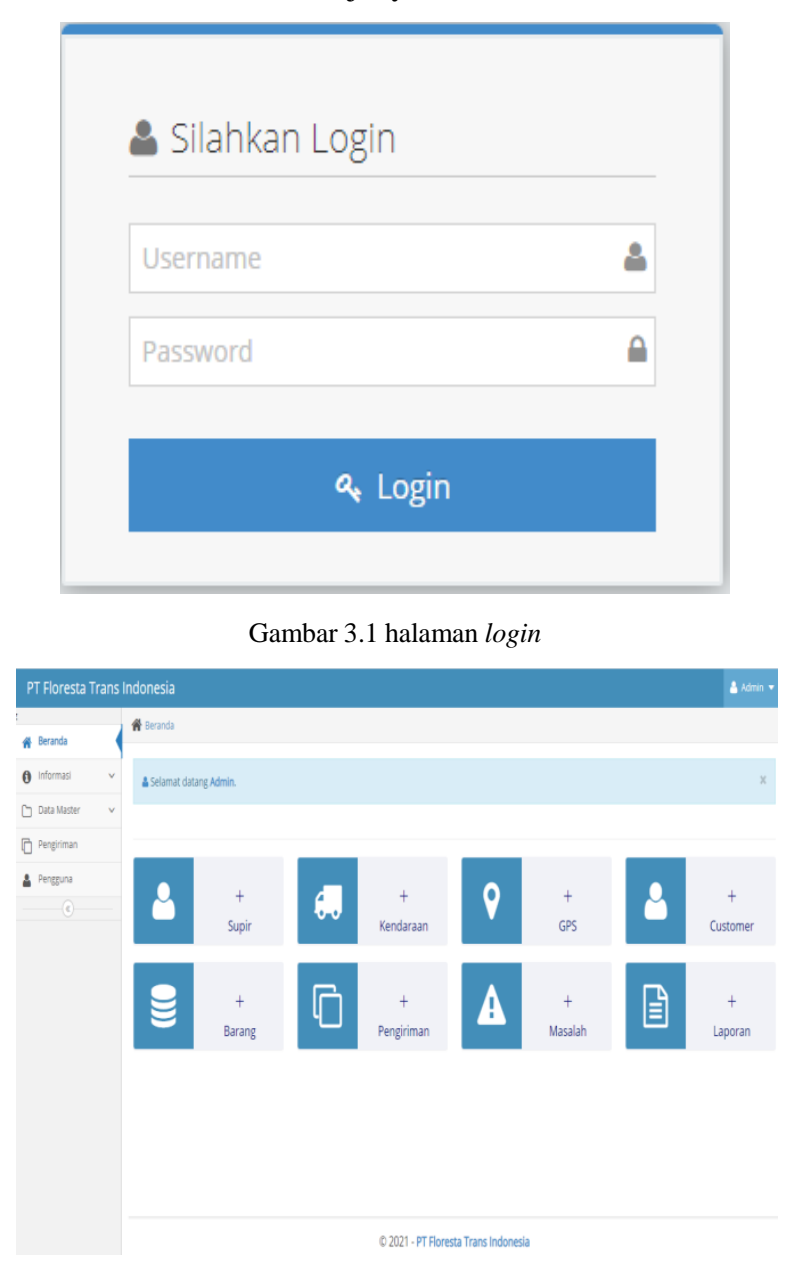

Gambar 3.2 halaman dashboard admin
Setelah itu admin memasukan data supir melalui form input data supir

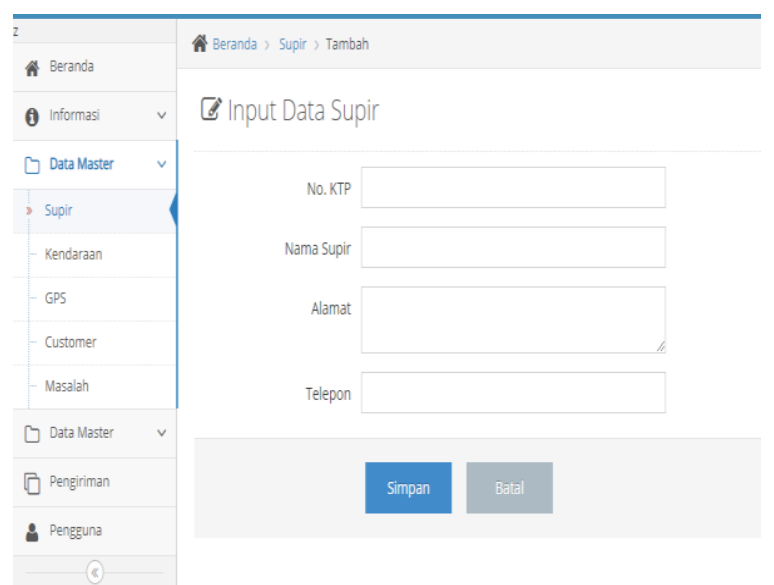

Gambar 3.3 halaman tambah data supir

setelah diisi dan disimpan lalu sistem akan menampilkan data supir yang sudah disimpan.

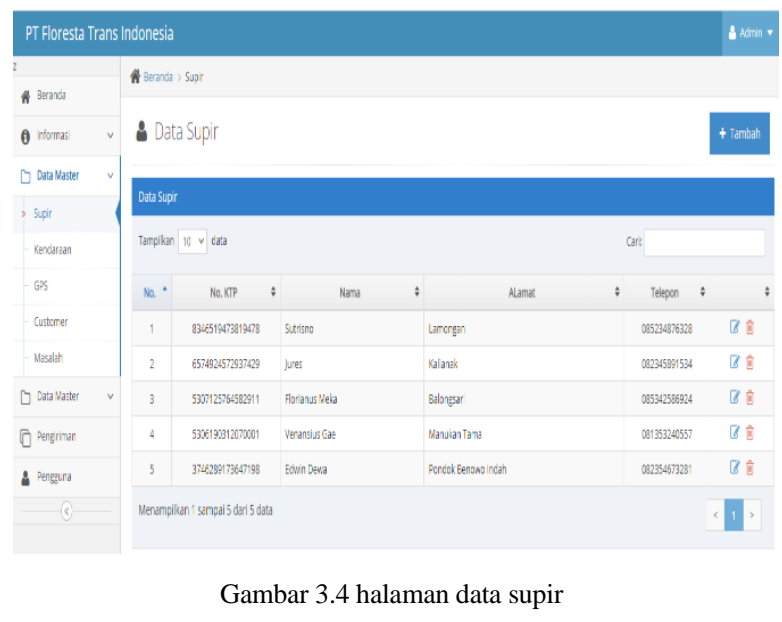

Setelah itu admin lanjut mengisi data gps melalui form input data gps. Dan setelah disimpan sistem akan menmpilkan data gps yang telah tersimpan

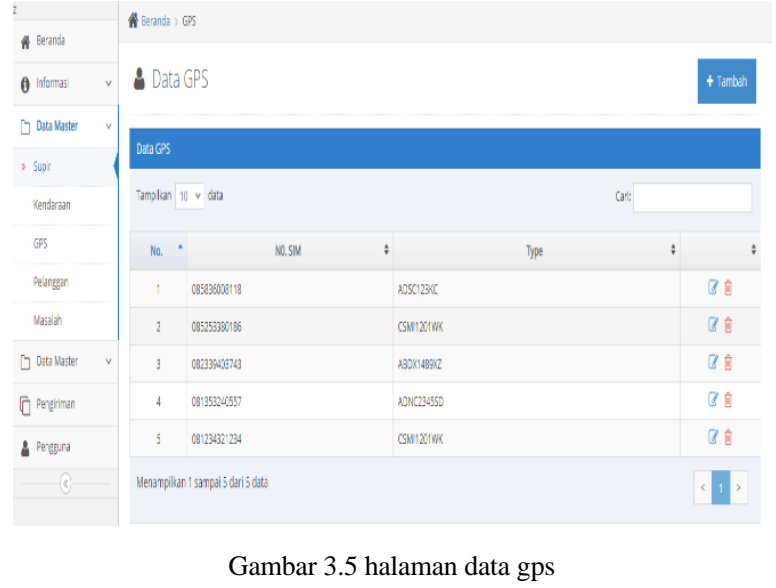

Setelah itu admin mengisi data kendaraan yang akan beroperasi dalam proses pengiriman barang. Setelah data kendaran disimpan maka sistem akan 
menampilkan data-data dari kendaraan yang telah tersimpan.

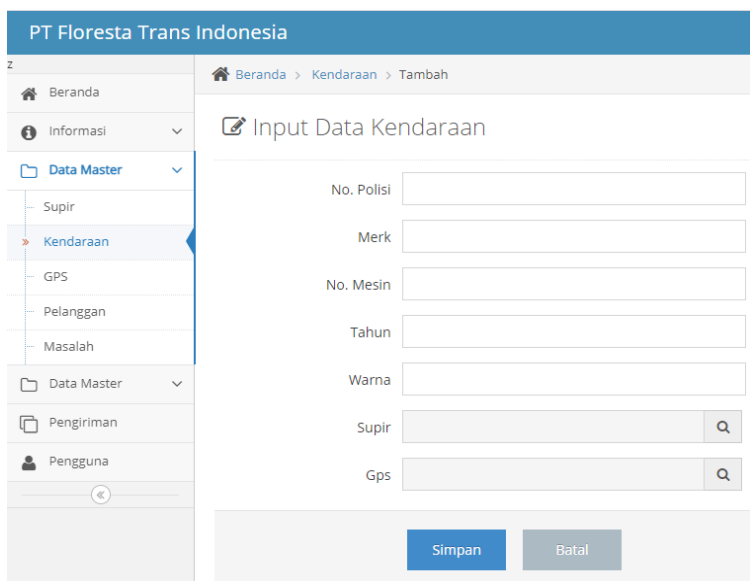

Gambar 3.6 halaman tambah data kendaraan

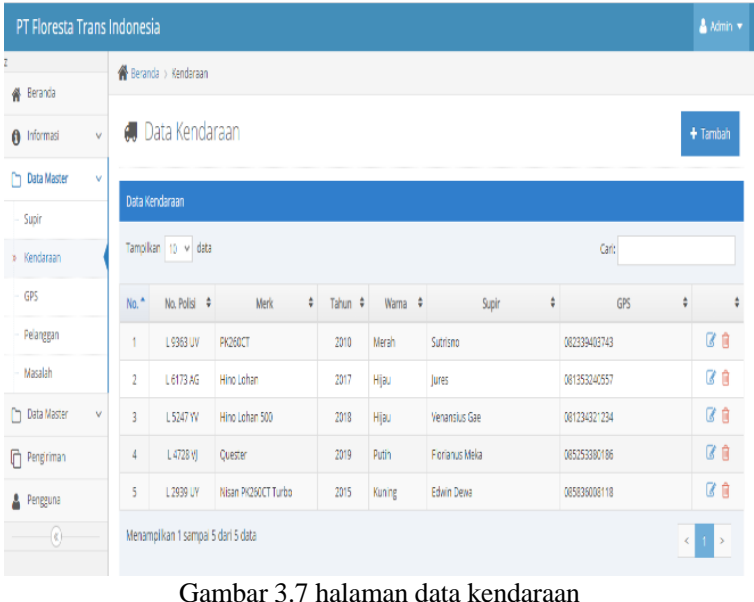

Selanjutnya admin mengisi data barang apa saja yang di impor dari luar negeri.

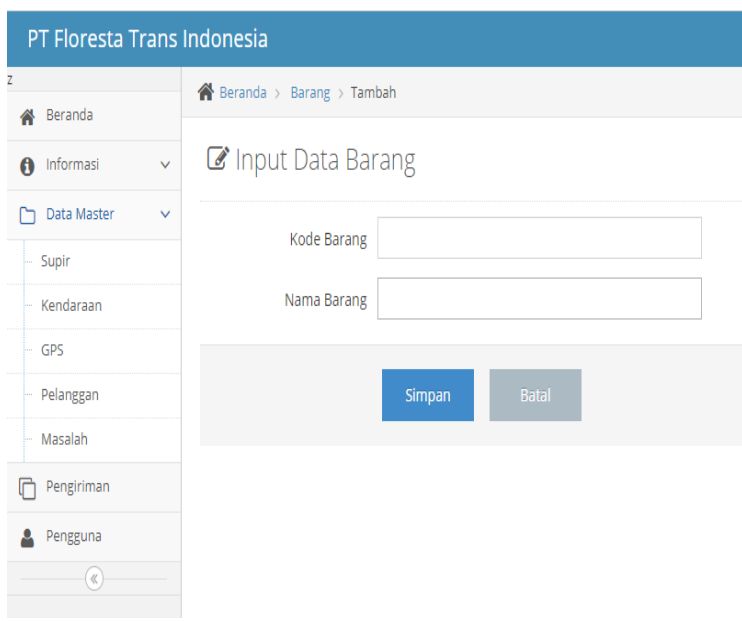

Gambar 3.8 halaman tambah data barang

Setelah itu admin mengisi data customer yang melakukan proses pengimporan barang. Setelah diisi maka sistem akan menapilkan data customer yang telah disimpan.

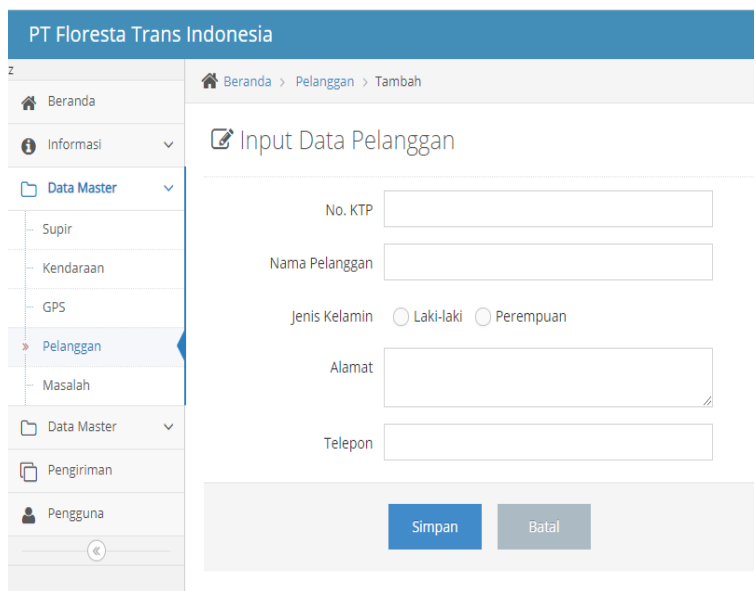

Gambar 3.9 halaman tambah data customer

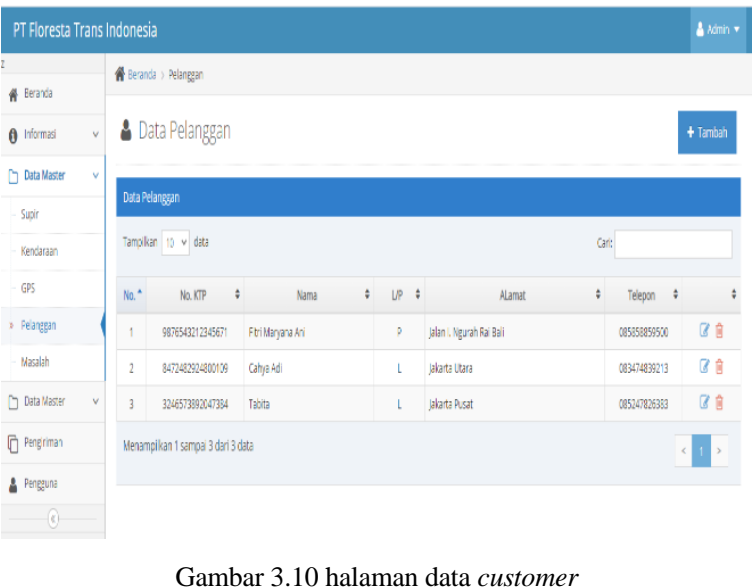

Selanjutnya admin memasukan data pengiriman barang melalui form pengiriman yang sudah disediakan, dan dalam proses penginputan data, terdapat beberapa data dimana admin langsung memilih data yang sudah tersimpan pada proses proses sebelumnya di atas.

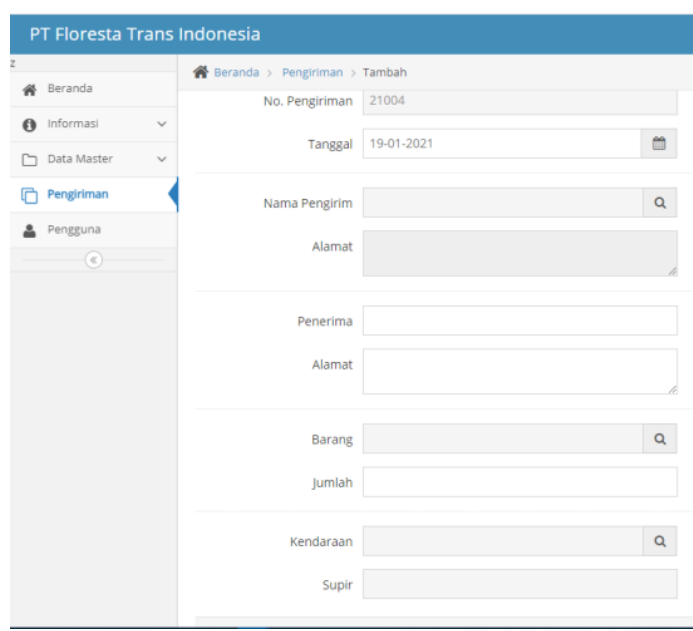

Gambar 3.11 halaman tambah data pengiriman 
Proses selanjutnya ketika disimpan, sistem akan menampilkan data pengiriman yang telah tersimpan.

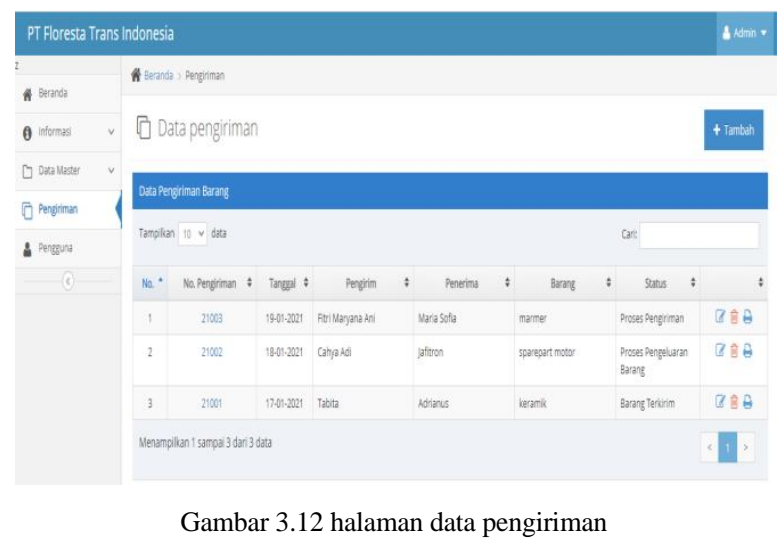

Setelah data tersimpan selanjutnya dapat diakses oleh customer. Customer memasukan data kode resi pada form cek resi yang sudah disediakan.

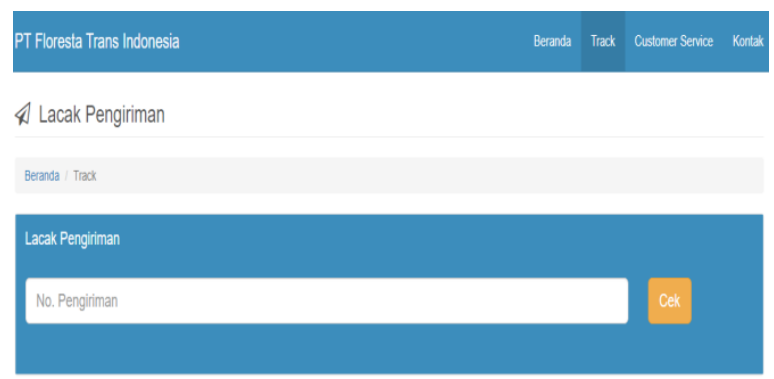

Gambar 3.13 halaman form cek resi

Setelah diinput dan klik tombol cek, sistem akan menampilkan informasi barang dan status dari pengiriman barang tersebut.

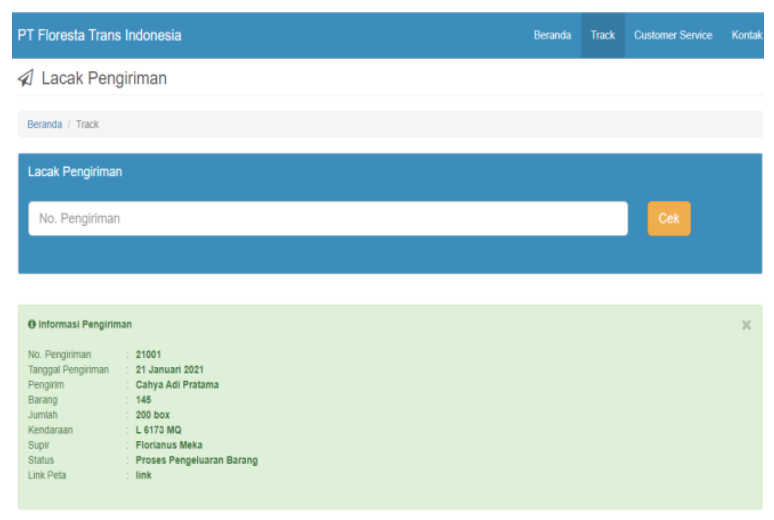

Gambar 3.14 halaman informasi pengiriman barang

\subsubsection{Uji Coba Proses Pemantauan Lokasi Barang yang Dikirim}

Untuk proses menampilkan informasi lokasi barang, customer langsung mengklik link yang sudah tersedia pada halaman informasi pengiriman barang, dan sistem akan menampilkan halaman peta melalui google maps.

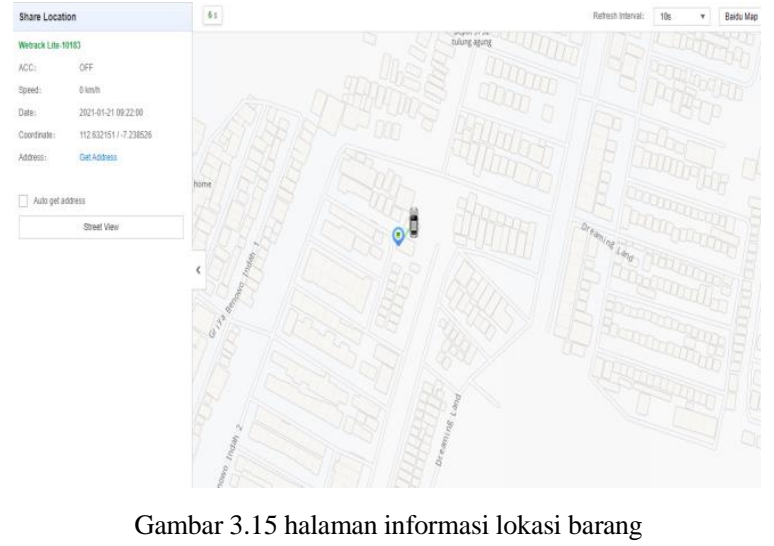

\subsubsection{Uji coba proses layanan customer service}

Pada proses ini mula - mula customer memasukan data keluhan seputar pengiriman barang melalui form layanan customer service.

\section{PT Floresta Trans Indonesia}

$\varpi$ Customer Service

Beranda / Customer Service

Send your question. Soon we will contact you.

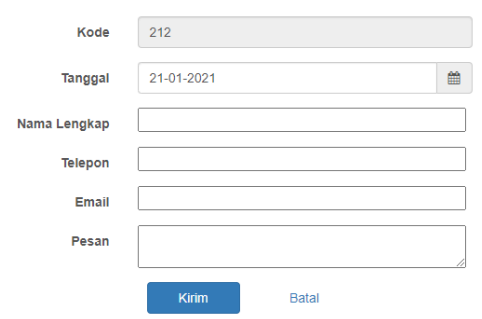

Gambar 3.16 halaman form input data permasalahan

Setelah menginput data permasalahan akan tersimpan di halaman kerja customer service. Dan selanjutnya customer service akan merespon dan menanggapi keluhan dari customer dengan menghubungi customer melalui telepon atau email sesuai data yang diinput oleh customer.

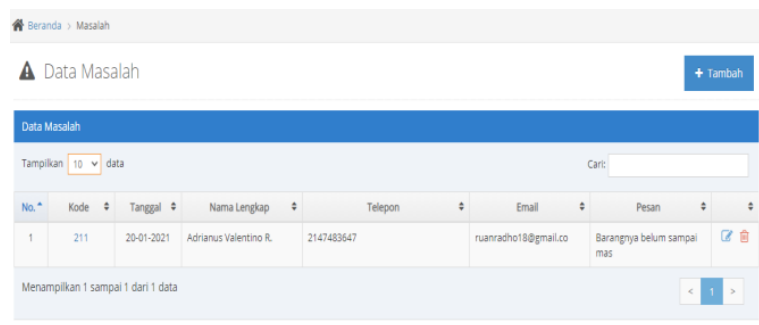

Q 2021. PT Floresta Trans Indonesia

Gambar 3.17 halaman data permasalahan pada dashboard customer service 


\subsubsection{Uji coba proses menampilkan informasi barang yang dimiliki customer}

Pada tahap ini pertama admin membuka halaman data pengiriman seperti pada gambar 3.18 di atas. Selanjutnya admin masuk pada tombol pencarian lalu memasukan data nama pelanggan yang ingin dicari list data pengirimannya. Selanjutnya sistem akan menampilkan data pengiriman sesuai dengan data nama yang dicari.

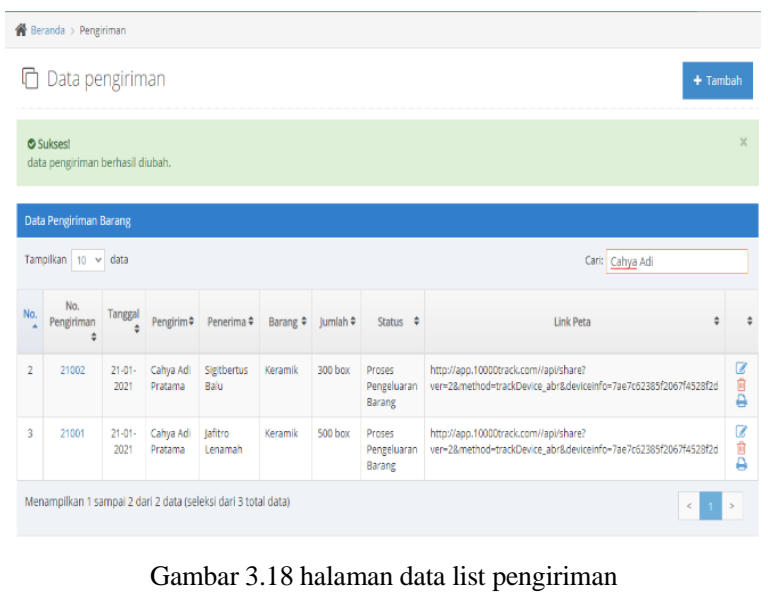

\subsection{Analisa Uji Coba Sistem}

Pada tahap analisa ujicoba sistem, akan dilakukan pembuktian apakah sistem berjalan sesuai dengan proses ujicoba atau tidak.

\subsubsection{Analisa menampilkan informasi status barang}

Pada Output yang telah ditampilkan pada Sub bab 3.1.1 telah dibuktikan bahwa informasi tersebut benar, hal tersebut ditunjukkan dengan tabel database pada gambar berikut.

\subsubsection{Analisa menampilkan proses pemantauan barang}

Pada Output yang telah ditampilkan pada Sub bab

3.1.2 telah dibuktikan bahwa informasi peta yang dimunculkan tersebut benar, hal tersebut ditunjukan dengan tampilan peta pada smartphone yang mengakses aplikasi tambahan untuk pemantauan, dimana titik kendaraan berada pada posisi yang sama.

\subsubsection{Analisa menampilkan layanan customer service}

Pada Output yang telah ditampilkan pada Sub bab 3.1.3 telah dibuktikan bahwa informasi tersebut benar, hal tersebut ditunjukkan dengan tabel database pada gambar berikut.

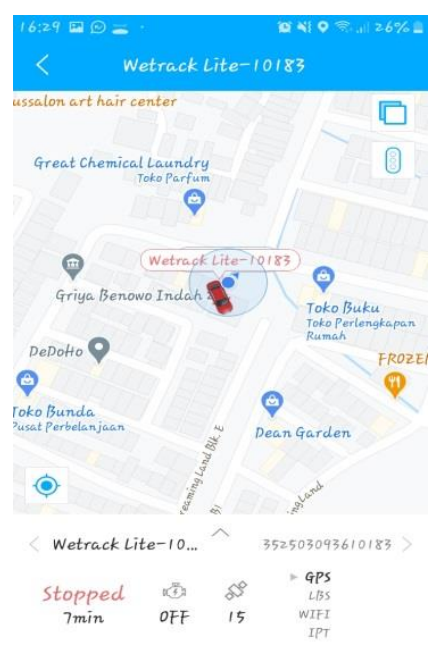

Gambar 3.20 analisa tampilan lokasi barang pada aplikasi tracksolid

\subsubsection{Analisa menampilkan informasi barang tiap customer}

Pada Output yang telah ditampilkan pada Sub bab 3.1.4 telah dibuktikan bahwa informasi tersebut benar, hal tersebut ditunjukkan dengan tabel database pada gambar berikut.

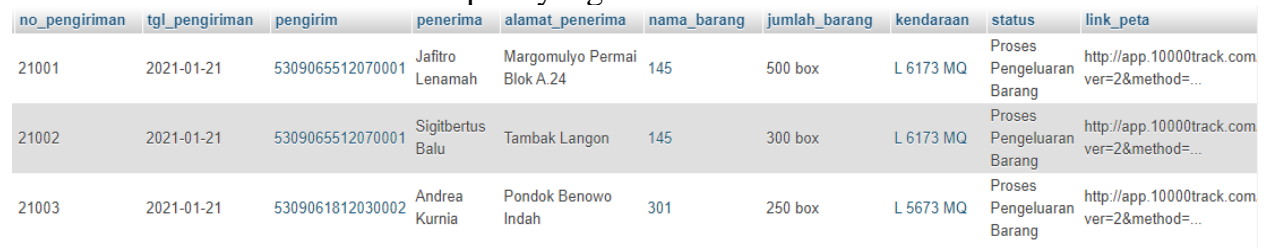

Gambar 3.19 analisa database tabel pengiriman

\begin{tabular}{|c|c|c|c|c|c|c|c|c|c|}
\hline no_pengiriman & tgl_pengiriman & pengirim & penerima & alamat_penerima & nama_barang & jumlah_barang & kendaraan & status & link_peta \\
\hline 21001 & 2021-01-21 & 5309065512070001 & $\begin{array}{l}\text { Jafitro } \\
\text { Lenamah }\end{array}$ & $\begin{array}{l}\text { Margomulyo Permai } \\
\text { Blok A.24 }\end{array}$ & 145 & 500 box & L $6173 \mathrm{MQ}$ & $\begin{array}{l}\text { Proses } \\
\text { Pengeluaran } \\
\text { Barang }\end{array}$ & $\begin{array}{l}\text { hittp.//app. } 10000 \text { track.co } \\
\text { ver=28method }=. .\end{array}$ \\
\hline 21002 & 2021-01-21 & 5309065512070001 & $\begin{array}{l}\text { Sigitbertus } \\
\text { Balu }\end{array}$ & Tambak Langon & 145 & 300 box & L $6173 \mathrm{MQ}$ & $\begin{array}{l}\text { Proses } \\
\text { Pengeluaran } \\
\text { Barang }\end{array}$ & $\begin{array}{l}\text { http./lapp. } 10000 \text { track.co } \\
\text { ver=28method=.. }\end{array}$ \\
\hline
\end{tabular}

Gambar 3.21 analisa tampilan database masalah 


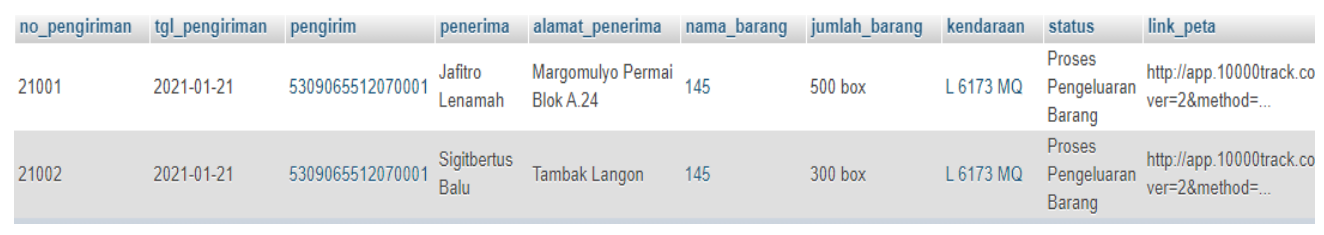

Gambar 3.22 analisa tampilan database masalah

\section{PENUTUP}

\subsection{Kesimpulan}

Berdasarkan hasil dan analisa terhadap Sistem Pelacakan Ekspedisi untuk barang impor pada PT. Floresta Trans Indonesiayang telah dibuat, maka diambilah kesimpulan sebagai berikut :

1. Sistem pelacakan ekspedisi untuk barang impor pada PT. Floresta Trans Indonesia dapat membantu customer dalam memantau posisi dari barang secara real time

2. Sistem pelacakan ekspedisi untuk barang impor pada PT. Floresta Trans Indonesia dapat membantu customer untuk mengetahui informasi status barang yang dikirim

3. Sistem pelacakan ekspedisi untuk barang impor pada PT. Floresta Trans Indonesia dapat membantu memfasilitasi pertanyaan dan keluhan bagi customer yang bermasalah dengan barang kiriman.

4. Sistem pelacakan ekspedisi untuk barang impor pada PT. Floresta Trans Indonesia dapat membantu menampilkan informasi daftar muatan barang yang dimiliki oleh setiap customer

\subsection{Saran}

Saran dari hasil dan analisa terhadap Sistem Pelacakan Kendaraan untuk Barang Impor pada PT. Floresta Trans Indonesia agar dapat dikembangkan lebih lanjut agar lebih baik kedepannya, yaitu sebagai berikut :

1. Untuk pelacakan langsung ditampilkan di web tanpa diakses melalui aplikasi tambahan

2. Dapat menambah tools tambahan untuk memperkuat sinyal gps agar dapat dijangkau oleh daerah terpencil dan di terowongan

3. Tambahkan history perjalanan dari kendaraan pengirim barang

\section{DAFTAR PUSTAKA}

[1] Ervina, 29 November 2019, "Peran Penting Teknologi bagi Perkembangan Perusahaan", Insight Talenta.

(https://www.talenta.co/blog/insighttalenta/peran-penting-teknologi/)

[2] PT. Floresta Trans Inonesia. (https://florestatrans.business.site/)

[3] TiGaDo, 30 September 2016, "Devinisi dan Pengertian Freigh Forwarding". (http://samuelsmart96.blogspot.com/2016/09/de finisi-dan-pengertian-freight.html)
[4] Jogianto, Sarjanaku.com, "Blog Pendidikan Indonesisa”, november 2005. [Online]. Available:

http://www.sarjanaku.com/2012/11/pengertiansistem-menurut-para-ahli.html. [Accessed 12 november 2019].

[5] Arvento, 2018 , "Apa Itu Sistem Pelacakan Kendaraan ? " [online]. https://www.arvento.com/id/apa-itu-sistempelacakan-kendaraan

[6] KBBI, 2016. "Kamus Besar Bahasa Indonesia (KBBI) ". [Online]

Available at: http://kbbi.web.id/pusat, [Diakses 20 Juni 2020].

[7] Abidin, Hasanudin Z, 2007, "Penentuan Posisi dengan GPS dan Aplikasinya" , Pradnya Paramita, Jakarta.

[8] Sommerville, I. 2011. "Software Engineering 9th Edition". Addison-Wesley.

[9] A.S Rosa dan Salahuddin M, 2011. Modul Pembelajaran Rekayasa Perangkat Lunak (Terstruktur dan Berorientasi Objek), Modula, Bandung.

[10] Pressman, R.S. (2010), Software Engineering : a practitioner's approach, McGraw-Hill, New York.

[11] Kendall \& Kendall. 2014. "Sistem Analysis and Design 9th edition". New Jersey: Rutgers University

[12] Jogiyanto, "Simbol dan tahapan data flow dyagram, Aplikasi penerimaan Siswa Baru", 2005.

[13] Pahlevy, 2010, "Pengertian Flowchatr" , Nganjuk-Jawa Timur

[14] Gregorius, "Pengertian Website", 2000 : 30.

[15] Andi, "Pengantar Teknologi Informasi", 2007.

[16] Kadir, "Perancangan Sistem Informasi Berbasis Web Pada Hotel Boutique Pesona Cikarang, Sistem Informasi Berbasis Web, Web Company Profile.”, p. 2, 2008.

[17] Kai 'Oswalad' Seidler and Kay Vogelgesang, "Pengertian Xampp," Dosen Pendidikan, 2014. [Online]. Available: https://www.dosenpendidikan.co.id/xamppadalah/. [Accessed 5 Desember 2019]. 